\title{
AFM Studies and Electrochemical Characterization of Boron-Doped Diamond Surfaces Modified with Metal Oxides by the Sol-Gel Method
}

\author{
Hugo B. Suffredini, Giancarlo R. Salazar-Banda, Sônia T. Tanimoto, Marcelo L. Calegaro, \\ Sergio A. S. Machado and Luis A. Avaca*
}

Instituto de Química de São Carlos, Universidade de São Paulo, CP 780, 13566-500 São Carlos - SP, Brazil

\begin{abstract}
Com o objetivo de aprofundar investigações anteriores, foram realizadas modificações superficiais diretas em eletrodos de diamante dopados com boro (DDB), com óxidos metálicos $\left(\mathrm{PtO}, \mathrm{RuO}_{2}\right.$, $\mathrm{IrO}_{2}$ e $\mathrm{PbO}_{2}$ ) e com alguns compósitos mistos, utilizando a técnica Sol-Gel. Estes materiais foram estudados por microscopia de força atômica (MFA) e os resultados indicaram a formação de sítios de deposição heterogênea. Técnicas eletroquímicas foram utilizadas para estabelecer a atividade catalítica para a reação de desprendimento de oxigênio (RDO) e para reação de oxidação de etanol em meio ácido utilizando os compósitos de $\mathrm{PtO}_{\mathrm{x}}$ e $\mathrm{PtO}_{\mathrm{x}}-\mathrm{RuO}_{2}$. Testou-se ainda a estabilidade de um depósito de $\mathrm{PtO}_{x}$, recoberto por um filme de $\mathrm{Nafion}^{\circledR}$, por meio de operação contínua de longa duração. Estudos de voltametria cíclica comparativa mostraram que a área superficial ativa dos novos materiais mudou consideravelmente com o método de modificação proposto. $\mathrm{O}$ eletrodo de $\mathrm{IrO}_{2} / \mathrm{BDD}$ mostrou o melhor desempenho para a RDO, iniciando o processo de oxidação em $\sim 1.4 \mathrm{~V}$ vs. HESS, valor este $200 \mathrm{mV}$ menor do que o observado sobre um eletrodo de $\mathrm{PtO}_{\mathrm{x}} / \mathrm{BDD}$. Foi observada uma pequena perda da atividade do eletrodo de $\mathrm{PtO}_{x} / \mathrm{BDD}(6 \%)$ depois de realizada eletrólise de 4 horas, enquanto que 1000 ciclos voltamétricos deixaram a superfície praticamente inalterada. Os estudos realizados mostram que as atividades satisfatórias dos eletrodos preparados pelo método Sol-Gel podem constituir ferramentas interessantes de pesquisa, visando principalmente a utilização destes materiais em aplicações práticas.
\end{abstract}

Continuing previous investigations, direct surface modifications of boron-doped diamond (BDD) electrodes with metal oxides $\left(\mathrm{PtO}_{x}, \mathrm{RuO}_{2}, \mathrm{IrO}_{2}\right.$ and $\left.\mathrm{PbO}_{2}\right)$ and with some mixed composites were carried out by the Sol-Gel technique. The materials were studied by atomic force microscopy (AFM) to determine their surface topologies and by electrochemical techniques to establish the catalytic activity towards the oxygen evolution reaction (OER) and also, for the $\mathrm{PtO}_{\mathrm{x}}$ and $\mathrm{PtO}_{\mathrm{x}}$ $\mathrm{RuO}_{2}$ composites, the ethanol oxidation reactions in acid media. The stability of $\mathrm{PtO}_{\mathrm{x}}$ coating covered by a Nafion ${ }^{\circledast}$ film was also tested by long-term operation. The AFM results indicated sites of heterogeneous deposition and the electrochemical studies demonstrated that the active surface area changed considerably with the proposed method of modification. The $\mathrm{IrO}_{2} / \mathrm{BDD}$ electrode showed the best performance to the OER with the onset of the oxidation current at $\sim 1.4$ $\mathrm{V}$, a value $200 \mathrm{mV}$ lower than for the $\mathrm{PtO} / \mathrm{BDD}$ electrode. The enhanced stability of $\mathrm{PtO} / \mathrm{BDD}$ electrodes achieved by the application of a Nafion ${ }^{\circledR}$ film and already reported in acid media was further proved using the ethanol oxidation reaction. Only a small loss of activity $(6 \%)$ was observed after 4-hours electrolysis while one-thousand voltammetric cycles left the surface practically unchanged. In addition, preliminary studies for the same reaction on $\mathrm{PtO}_{\mathrm{x}} / \mathrm{BDD}$ and $\mathrm{PtO}_{\mathrm{x}}-\mathrm{RuO}_{2} /$ BDD electrodes demonstrated the excellent activity of these mixed Sol-Gel coatings on the BDD surface and the possibility of further investigations for practical applications.

Keywords: modified diamond electrodes, Sol-Gel technique, metal oxides

\section{Introduction}

Boron-doped diamond (BDD) films have been largely used as electrode material in electroanalytical studies ${ }^{1-7}$

* e-mail: avaca@iqsc.usp.br since they posses an extraordinary chemical stability, low capacitive currents in an extended range of potentials and good reproducibility of the results if adequately pretreated. ${ }^{89}$ Taking advantage of these qualities, several authors have also used BDD electrodes to study the oxidation or electrochemical combustion of organic 
compounds, particularly for the wastewater treatment. ${ }^{10-13}$ In addition, modifications of the BDD surface have been employed for a number of specific applications. ${ }^{14-30}$

Thus, Duo et al. ${ }^{14}$ have studied the deposition of small quantities of $\mathrm{IrO}_{2}$ clusters on the BDD surface by a thermal decomposition technique and observed that the oxygen evolution reaction (OER) was dramatically enhanced with the surface modification. De Battisti et al. ${ }^{15}$ have reported Sol-Gel modifications of the BDD surface with $\mathrm{RuO}_{2}$ and $\mathrm{IrO}_{2}$ and used chlorine evolution as a model reaction to evaluated the effect of $\mathrm{RuO}_{2}$ modification on BDD films. They showed that the catalytic activity of the $\mathrm{RuO}_{2} / \mathrm{BDD}$ electrode was much higher in comparison to the unmodified BDD and also observed that the chlorine evolution reaction at the $\mathrm{RuO}_{2} / \mathrm{BDD}$ electrode proceeds with a higher rate than on $\mathrm{RuO}_{2} / \mathrm{Ti}$ electrode. Terashima et al. ${ }^{16}$ have demonstrated that a regular dispersion of iridium oxide nanoparticles or a continuous oxide films could be obtained on BDD surfaces using a electrodeposition method, with excellent control of the amount deposited and high reproducibility of the electrochemical performance for the amperometric detection of hydrogen peroxide. Salimi et $a l .{ }^{17}$ studied the behavior of BDD surfaces modified with $\mathrm{IrO}_{2}$ by an electrodeposition method for the detection of arsenic (III) in real samples and found that the modified electrodes showed an excellent analytical performance with detection limit of $2 \mathrm{mmol} \mathrm{L}^{-1}$ of arsenic (III). More recently, BDD surface modifications were proposed using chemical, ${ }^{18}$ electrochemical $^{19}$ and ion implantation techniques. ${ }^{20}$

Methanol oxidation was studied by Montilla et al. ${ }^{21}$ on a Pt-modified diamond electrode. Platinum particles were deposited on the BDD surface by conventional chemical or electrochemical methods. The stability of the deposited Pt was very low, but the activity for methanol oxidation was satisfactory. Meanwhile, in a very recent Communication to this Journal, Salazar-Banda et al.$^{22}$ have shown great improvements in the stability of $\mathrm{PtO}_{\mathrm{x}}$ particles deposited on the BBD surface by the Sol-Gel method. The authors used a thermal pre-treatment of the surface before applying the Sol-Gel coating and then the electrode surface was covered by a Nafion ${ }^{\circledR}$ film. This procedure yielded electrodes that retained over $90 \%$ of the coated material after one-thousand voltammetric cycles carried out between the water decomposition reactions. Thus, the use of the Sol-Gel method together with the application of a Nafion ${ }^{\circledR}$ film on top of the coating preserved almost integrally the deposited platinum oxide.

The electrocatalytic activities for oxygen reduction and methanol oxidation at a boron-doped nanoporous honeycomb diamond films, modified with Pt nanoparticles by immersion of electrodes in $\mathrm{H}_{2} \mathrm{PtCl}_{6}$ aqueous solution and subsequent $\mathrm{Pt}$ reduction by a 3 hours exposure to flowing $\mathrm{H}_{2}$ gas at $580{ }^{\circ} \mathrm{C}$, was examined with cyclic voltammetry and electrochemical impedance spectroscopy in acid solution by Honda et al. ${ }^{23}$ These boron-doped nanoporous honeycomb diamond electrodes were also electrochemically characterized in non-aqueous electrolytes by Yoshimura et al. ${ }^{24}$ In other work, nanometer-size metal particles of $\mathrm{Ag}, \mathrm{Au}, \mathrm{Pd}$ and others with preferred crystalline textures were spontaneously deposited on a diamond thin film by Gao et al. ${ }^{25}$ The deposition was achieved after immersion in an acidic solution containing metal ions or complex metal ions and a significant enhancement of hydrogen evolution activity was observed on a diamond electrode modified by $9 \%$ coverage of $\mathrm{Pd}$ nanoparticles.

On the other hand, is well established in the literature that Sol-Gel is a feasible coating method and have been used for different purposes. Thus, Mattos-Costa et al. ${ }^{26}$ have constructed $\mathrm{Ti} / \mathrm{Ru}_{\mathrm{x}} \mathrm{Ir}_{1-\mathrm{x}} \mathrm{O}_{2}$ electrodes to be used as anodes under extreme conditions and Suffredini et al. ${ }^{27}$ have prepared $\mathrm{NiCo}_{2} \mathrm{O}_{4}$ coatings on Ni using the Sol-Gel method to produce an efficient material for oxygen evolution in alkaline media. Several other authors have prepared Sol-Gel films of Ga-Zn oxide ${ }^{28}$ as well as tetraethoxysilane (TEOS) and methyltriethoxysilane (MTEOS)-based films ${ }^{29}$ were prepared to be used as oxygen sensors while, for the first time, modified carbon powder electrodes were recently produced by the Sol-Gel method to be used as anodes in direct methanol fuel cells. ${ }^{30}$

The aim of this work is to extend our previous findings on the Sol-Gel modification of the BDD surface ${ }^{22}$ to different catalytic coatings such as metal oxides $\left(\mathrm{MO}_{2}, \mathrm{M}\right.$ $=\mathrm{Pb}, \mathrm{Ru}$, and $\mathrm{Ir}$ ) and analyze their surface topologies by atomic force microscopy (AFM) and electrochemical active area by comparative studies with a polycrystalline Pt electrode. These new materials will be tested as anodes for the oxygen evolution reaction (OER) in acid media. In addition, the ethanol oxidation reaction will be used to confirm the stability of the Pt oxide deposit made by the Sol-Gel technique and covered by a Nafion ${ }^{\circledR}$ film as well as the catalytic activity of the $\mathrm{MO}_{2}$ coatings towards this last and very important electrode reaction.

\section{Experimental}

\section{Reagents and apparatus}

The electrochemical experiments were performed at room temperature in a Pyrex ${ }^{\circledR}$ glass cell provided with three electrodes and degassing facilities for bubbling $\mathrm{N}_{2}$. The reference electrode was the hydrogen system in the 
same solution (HESS) and all potentials are referred to this system while the auxiliary one was a $2 \mathrm{~cm}^{2} \mathrm{Pt}$ foil.

The reagents used in this work were all of Merck P.A. quality and the water was purified by the Milli-Q system from Millipore. The Sol-Gel solutions were prepared with $\mathrm{Ru}$ (III), Ir (III), $\mathrm{Pb}$ (II) and Pt (II) acetylacetonates in a mixture of ethanol + acetic acid $(3: 2, \mathrm{v} / \mathrm{v})$. The final concentration of these solutions was $0.01 \mathrm{~mol} \mathrm{~L}^{-1}$. A $5 \%$ Nafion ${ }^{\circledast}$ solution in a mixture of lower aliphatic alcohols and water (Sigma-Aldrich) was used for coating the deposits.

The comparative cyclic voltammetries, aiming to determine the electrochemical active areas, were performed in a $1.0 \times 10^{-2} \mathrm{~mol} \mathrm{~L}^{-1} \mathrm{~K}_{4} \mathrm{Fe}(\mathrm{CN})_{6}+0.5 \mathrm{~mol} \mathrm{~L}^{-1} \mathrm{H}_{2} \mathrm{SO}_{4}$ solution while the OER studies were carried out in $0.5 \mathrm{~mol}$ $\mathrm{L}^{-1} \mathrm{H}_{2} \mathrm{SO}_{4}$ solution. The ethanol oxidation reaction was studied in a $0.5 \mathrm{~mol} \mathrm{~L}^{-1} \mathrm{CH}_{3} \mathrm{CH}_{2} \mathrm{OH}+0.5 \mathrm{~mol} \mathrm{~L}^{-1} \mathrm{H}_{2} \mathrm{SO}_{4}$ solution by cyclic and linear voltammetry and control potential electrolysis. All electrochemical measurements were carried out in a Mod. 283 EG\&G PARC instrument and the surface topology studies were performed using an atomic force microscope TopoMetrix ${ }^{\circledR}$ AFM Explorer.

\section{Working electrodes preparation}

Boron-doped diamond (BDD) electrodes were prepared by the Centre Suisse de Electronique et de Microtechnique SA (CSEM), Switzerland, using the hot filament chemical vapor deposition (HF-CVD) technique with a filament temperature in the range $2440-2560{ }^{\circ} \mathrm{C}$ and a gaseous mixture containing methane, $\mathrm{H}_{2}$ and trimethylboron. The final boron content was of the order of 4500-5000 ppm. The BDD plates were used as working electrode and as substrate for the surface modifications carried out by the Sol-Gel method. A thermal pre-treatment at $400{ }^{\circ} \mathrm{C}$ was applied for $30 \mathrm{~min}$ to the BDD prior to the coatings deposition. The $\mathrm{Pt}$ (II), $\mathrm{Pb}$ (II), Ru (III) or Ir (III) acetylacetonate solutions, described in the previous section, were transferred to the diamond surface by the painting technique. Then, the solution was evaporated for 5 minutes at a temperature of $80{ }^{\circ} \mathrm{C}$ in a stove. This procedure was repeated for five times for the $\mathrm{IrO}_{2} / \mathrm{BDD}$, $\mathrm{RuO}_{2} / \mathrm{BDD}$ and $\mathrm{PbO}_{2} / \mathrm{BDD}$ electrodes and ten times for the $\mathrm{PtO}_{x} / \mathrm{BDD}$ and $\mathrm{PtO}_{x}-\mathrm{RuO}_{2} / \mathrm{BDD}$ electrodes. Finally, the coated electrodes were submitted to a thermal treatment at $400{ }^{\circ} \mathrm{C}$ for 1 hour in an Argon atmosphere.

The $\mathrm{PtO}_{\mathrm{x}} / \mathrm{BDD}$ electrode used to perform the ethanol oxidation and the durability studies received a Nafion ${ }^{\circledR}$ film to improve the stability of the coating on the diamond surface. ${ }^{22}$ Thus, $40 \mu \mathrm{L}$ of the Nafion ${ }^{\circledR}$ solution diluted to $0.5 \%$ was evaporated onto the electrode surface (geometric area of $0.56 \mathrm{~cm}^{2}$ ) using a hot air stream. The Pt working electrode used for comparative studies was a foil with $0.18 \mathrm{~cm}^{2}$ of geometric area and was cleaned using conventional chemical and electrochemical techniques.

\section{Results and Discussion}

Figure 1 shows the AFM images $(10 \times 10 \mu \mathrm{m})$ for the BDD surface and for the different modified electrodes. The BDD topology presents regular pyramidal structures and it is similar to those already reported in the literature. ${ }^{31,32}$ For the modified structures, the same regularity can be observed but with the presence of some metallic oxide "islands". For all BDD-modified samples, some agglomerations of metallic oxides can be observed indicating sites of heterogeneous deposition.

To exclude the possibility that enhanced oxidation currents could be due to surface roughness and not to a real catalytic effect, a rough estimate of the electrochemical active area of the modified electrodes was carried out. Thus, the voltammetric experiments shown in Figure 2 were recorded in $0.5 \mathrm{~mol} \mathrm{~L}^{-1} \mathrm{H}_{2} \mathrm{SO}_{4}+10^{-2} \mathrm{~mol} \mathrm{~L}^{-1}$ $\mathrm{K}_{4} \mathrm{Fe}(\mathrm{CN})_{6}$ solutions except for that in the insert of Figure $2 \mathrm{~A}$ that was carried out in the pure $\mathrm{H}_{2} \mathrm{SO}_{4}$ solution. The insert presents a typical steady-state response of a polycrystalline Pt electrode in acid media. It is well established in the literature ${ }^{33-36}$ that the Pt electrochemical active area can be calculated by the H adsorption/ desorption charge density since for polycrystalline Pt surfaces, the occupation of all active sites of the surface with a complete monolayer of adsorbed hydrogen involves a charge of $210 \mu \mathrm{C} \mathrm{cm}^{-2}$. This charge density corresponds to the transfer of one electron to each one of the $1.3 \times 10^{15}$ atoms of Pt in $1 \mathrm{~cm}^{2}$ of its surface. ${ }^{37,38}$ In the present case, the calculated charge for desorbed $\mathrm{H}$ (dashed region in the voltammogram) was $66.60 \mu \mathrm{C}$ and the corresponding active area was equal a $0.317 \mathrm{~cm}^{-2}$. As the geometric area of the electrode was $0.181 \mathrm{~cm}^{2}$, the roughness factor for $\mathrm{Pt}$ was equal to 1.75 .

It is well recognized that for a typical outer-sphere and diffusion-controlled reaction, as it is the case for the $\mathrm{K}_{4} \mathrm{Fe}(\mathrm{CN})_{6} / \mathrm{K}_{3} \mathrm{Fe}(\mathrm{CN})_{6}$ redox couple in solution, the Randles-Sevick equation can be used:

$I_{p}=\left(2.69 \times 10^{5}\right) n^{3 / 2} A D_{0} v^{1 / 2} C_{0}^{*}$

where $I_{p}$ is the peak current, $n$ is the electrons number, $A$ is the active area of the electrode, $D_{o}$ is the diffusion coefficient, $v$ is the scan rate and $C_{o}{ }^{*}$ is the bulk concentration of the specie. Then, a relation between $I_{p}$ and $A$ can be established provided the reaction follows equation 1 . 

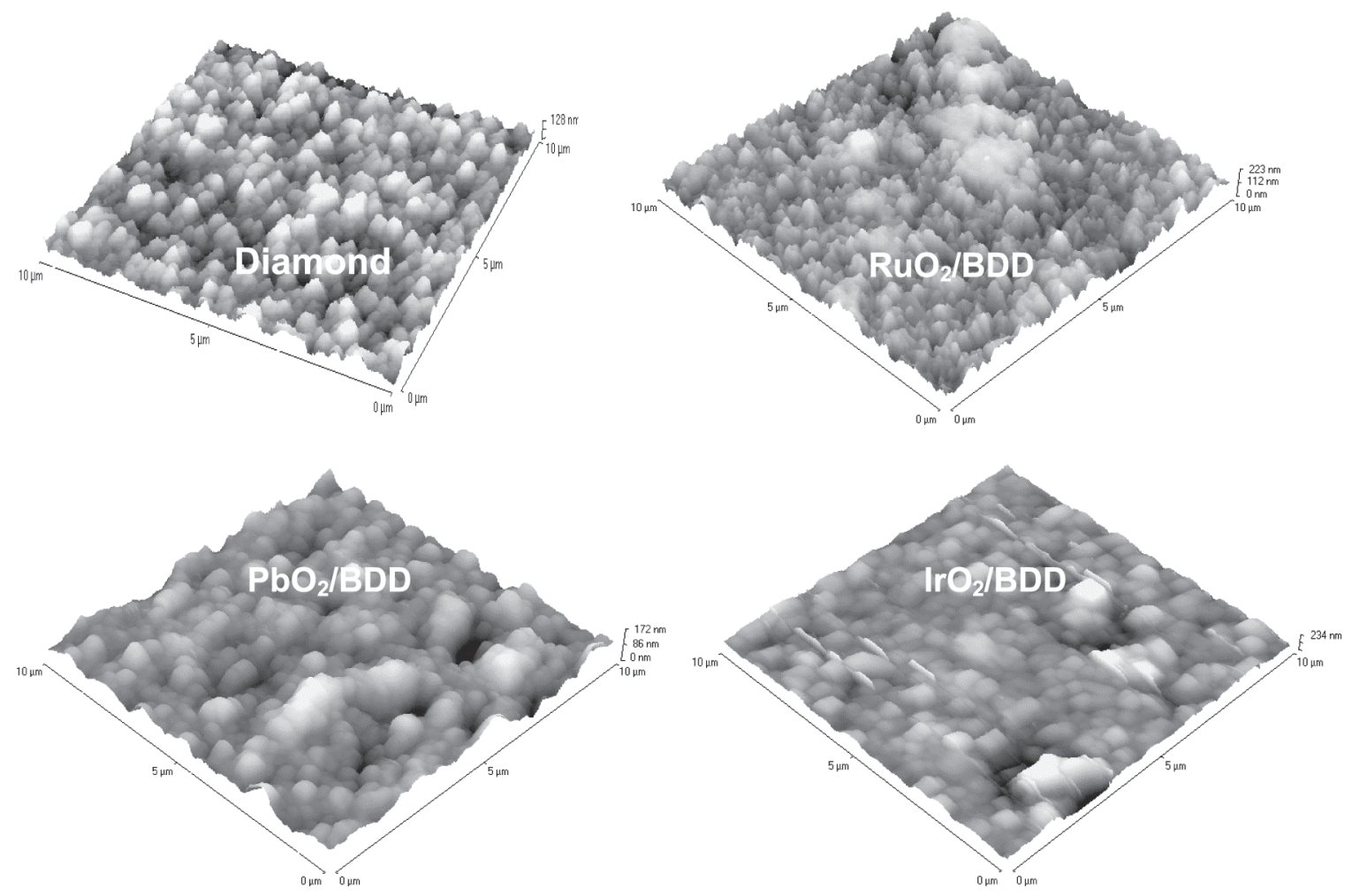

Figure 1. Topological studies carried out by the AFM technique $(10 \times 10 \mu \mathrm{m})$ for $\mathrm{BDD}, \mathrm{RuO}_{2} / \mathrm{BDD}, \mathrm{IrO}_{2} / \mathrm{BDD}$ and $\mathrm{PbO}_{2} / \mathrm{BDD}$.

Figure 2B shows the cyclic voltammograms for BDD, $\mathrm{PbO}_{2} / \mathrm{BDD}, \mathrm{RuO}_{2} / \mathrm{BDD}$ and $\mathrm{IrO}_{2} / \mathrm{BDD}$ in presence of a $10^{-2} \mathrm{~mol} \mathrm{~L}^{-1} \mathrm{~K}_{4} \mathrm{Fe}(\mathrm{CN})_{6}+0.5 \mathrm{~mol} \mathrm{~L}^{-1} \mathrm{H}_{2} \mathrm{SO}_{4}$ aqueous solution. Except for the case of $\mathrm{IrO}_{2} / \mathrm{BDD}$, the other systems show an acceptable reversibility for the intended comparison with the Pt response. Minor differences could be due to an internal resistance in the oxide layers while for DBB the reasons are mainly linked to the state of the surface prior to the experiment. ${ }^{8}$ On the other hand, the quasi-reversible response recorded for the $\mathrm{IrO}_{2} / \mathrm{BBD}$ electrode (Figure 2B) has been previously reported by Gottesfeld ${ }^{39}$ who observed that the $\mathrm{K}_{4} \mathrm{Fe}(\mathrm{CN})_{6} / \mathrm{K}_{3} \mathrm{Fe}(\mathrm{CN})_{6}$ redox couple in acid media showed a reversible behavior on an Ir rotating disk electrode that changed to irreversible when the electrode is covered by a Ir oxide layer, probably due to a blocking effect in the diffusion through the oxide film. Likewise, non-reversible behavior was observed for hydroquinone using an $\mathrm{IrO}_{x}$ electrode while a reversible response was observed for gold in a borate buffer solution. ${ }^{40}$

Therefore, using equation 2 (below) together with the response of the Pt electrode in the same solution (Figure $2 \mathrm{~A})$ an estimate of the active surface areas of the modified electrodes can be obtained:

$\frac{A(P t)}{I_{p}(P t)}=\frac{A(\operatorname{Mod} .)}{I_{p}(\operatorname{Mod} .)}$ where $A(P t)$ is the Pt active area, $I_{p}(P t)$ is the platinum peak current, $A(M o d$. $)$ is the active area of the modified electrode (or of the BDD surface) and $I_{p}$ (Mod.) is the peak current for the modified electrode. The active surface areas of the oxide-modified electrodes were then calculated and the values are presented in Table 1. These values will be used later for performance comparisons between the different materials.

Table 1. Electrochemical active areas and roughness factors for the BDD and the oxide-modified electrodes obtained by comparative cyclic voltammetries using a $\mathrm{Pt}$ electrode and a $10^{-2} \mathrm{~mol} \mathrm{~L}^{-1} \mathrm{~K}_{4} \mathrm{Fe}(\mathrm{CN})_{6}+0.5$ mol L-1 $\mathrm{H}_{2} \mathrm{SO}_{4}$ solution

\begin{tabular}{lccc}
\hline $\begin{array}{l}\text { electrode } \\
\text { material }\end{array}$ & $\begin{array}{c}\text { geometric } \\
\text { area }\left(\mathrm{cm}^{2}\right)\end{array}$ & $\begin{array}{c}\text { active area } \\
\left(\mathrm{cm}^{2}\right)\end{array}$ & $\begin{array}{c}\text { roughness } \\
\text { factor }\end{array}$ \\
\hline $\mathrm{PLATINUM}$ & 0.18 & 0.32 & 1.75 \\
$\mathrm{BDD}$ & 0.62 & 1.43 & 2.32 \\
$\mathrm{PbO}_{2} / \mathrm{BDD}$ & 0.55 & 2.58 & 4.72 \\
$\mathrm{RuO}_{2} / \mathrm{BDD}$ & 0.43 & 1.68 & 3.93 \\
$\mathrm{IrO}_{2} / \mathrm{BDD}$ & 0.46 & 1.71 & 3.75 \\
\hline
\end{tabular}

Figure 3 shows the electrochemical responses for the oxygen evolution reaction in acid media recorded on the different electrode materials. The reaction mechanism for the OER on a BDD electrode has already been reported ${ }^{41}$ indicating that the Diamond surface is not favorable for adsorption. Consequently, electrode processes that involve 

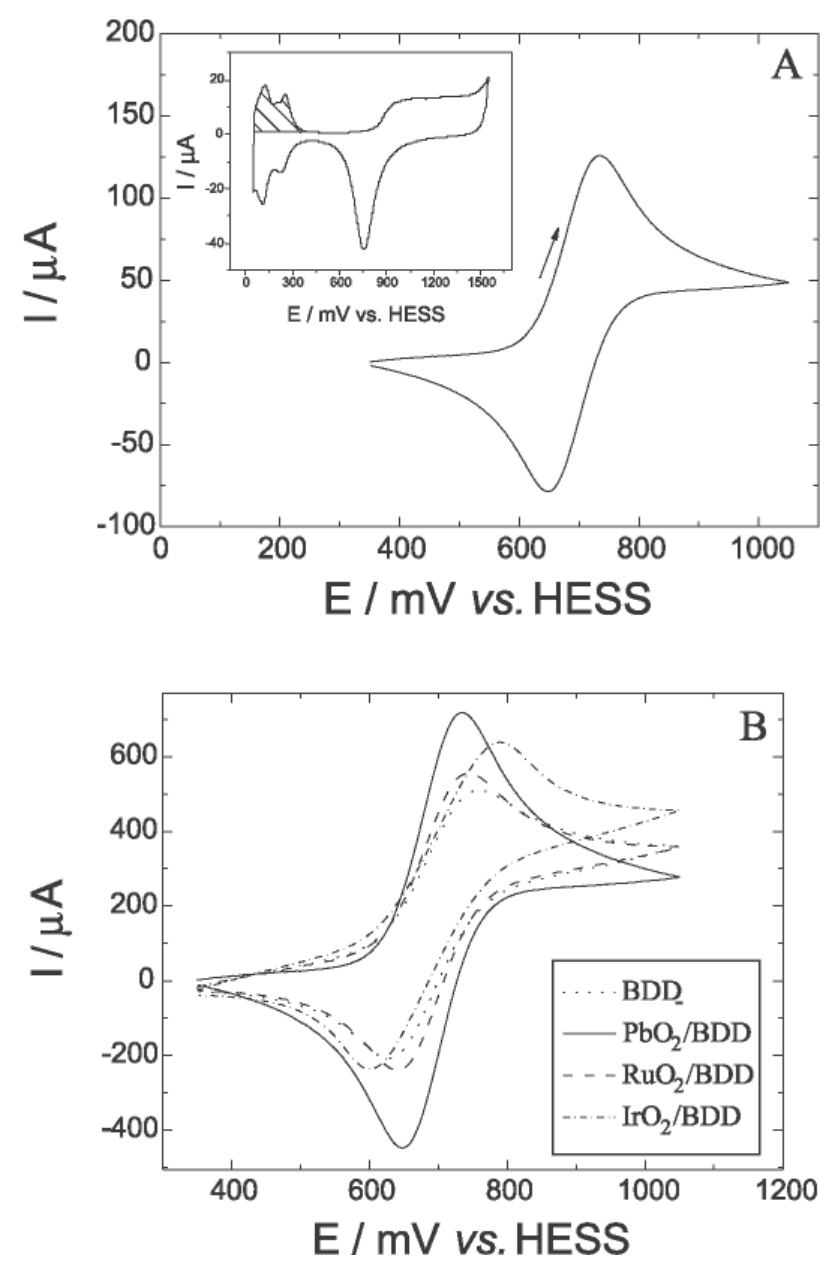

Figure 2. Comparative cyclic voltammograms ( $1^{\text {st }}$ cycle) to determine the active areas of the oxide-modified electrodes: (A) Pt electrode in a $1.0 \times 10^{-2} \mathrm{~mol} \mathrm{~L}^{-1} \mathrm{~K}_{4} \mathrm{Fe}(\mathrm{CN})_{6}+0.5 \mathrm{~mol} \mathrm{~L}^{-1} \mathrm{H}_{2} \mathrm{SO}_{4}$ solution; (B) responses for $\mathrm{BDD}$ (dotted line), $\mathrm{PbO}_{2} / \mathrm{BDD}$ (solid line), $\mathrm{RuO}_{2} / \mathrm{BDD}$ (dashed line) and $\mathrm{IrO}_{2} / \mathrm{BDD}$ (dash-dotted line) electrodes in the same solution. The Insert in (A) shows the Pt steady-state response in a pure $0.5 \mathrm{~mol} \mathrm{~L}^{-1}$ $\mathrm{H}_{2} \mathrm{SO}_{4}$ solution. $v=50 \mathrm{mV} \mathrm{s}^{-1}$.

adsorbed intermediates as in the case of the oxygen evolution reaction (OER) as well as for the oxidation of alcohols are strongly hindered on diamond. This is concluded from the fact that the initial adsorption is the rate-determining step for both water reactions and explains the wide electrochemical potential window for BDD in aqueous solutions..$^{41,42}$ Due to the lack of activity of the diamond electrode for adsorbed intermediate, its surface needs to be modified with catalysts for the activation of many interesting reactions.

The best performance for the OER was observed for the $\mathrm{IrO}_{2} / \mathrm{BDD}$ sample (Figure 3) with an onset potential of $\sim 1.4 \mathrm{~V} v s$. HESS and these results are in good agreement with previous work that describes similar studies on $\mathrm{IrO}_{2} /$ BDD electrodes deposited by thermal decomposition. ${ }^{14}$ They also agree with the results for $\mathrm{IrO}_{2} / \mathrm{ITO}$ electrodes

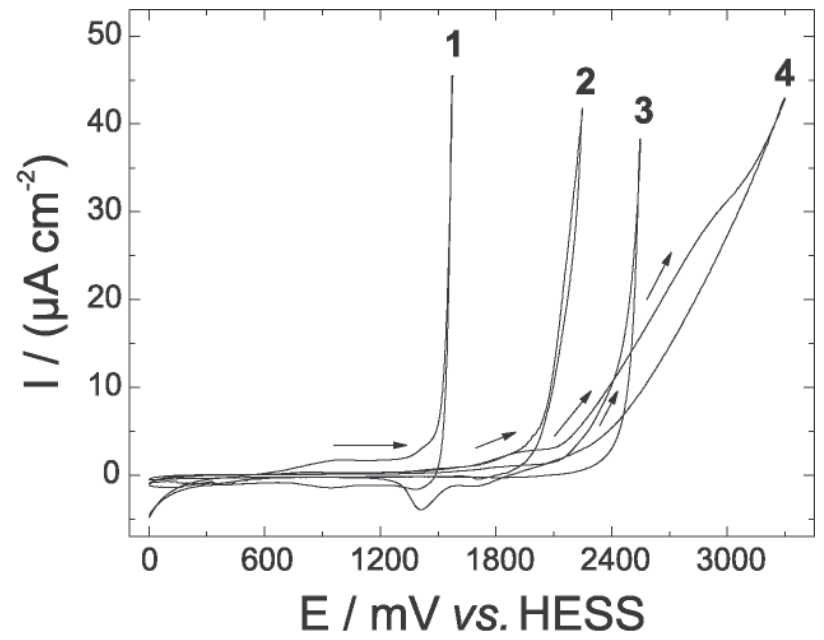

Figure 3. Cyclic voltammetric studies of the OER in $0.5 \mathrm{~mol} \mathrm{~L}^{-1} \mathrm{H}_{2} \mathrm{SO}_{4}$ for $\mathrm{IrO}_{2} / \mathrm{BDD}(1), \mathrm{RuO}_{2} / \mathrm{BDD}(2)$, non-modified $\mathrm{BDD}$ (3) and $\mathrm{PbO}_{2} / \mathrm{BDD}$ (4). The currents were normalized by the corresponding electrochemical active area (Table 1). $v=50 \mathrm{mV} \mathrm{s}^{-1}$.

deposited by electrodeposition ${ }^{43}$ and for $\mathrm{IrO}_{2}$ powders prepared by a pyrolytic process. ${ }^{44}$ It is important to notice that the onset potential for the OER ( 1.4 V vs. HESS) obtained on the $\mathrm{IrO}_{2} / \mathrm{BDD}$ electrode has a similar value to that obtained using elaborated binary and ternary electrodes, i.e., $\mathrm{Ti} / \mathrm{RuO}_{2}-\mathrm{Nb}_{2} \mathrm{O}_{5}$ electrodes prepared by the polymeric precursor method ${ }^{45}$ and for $\mathrm{Ti} / \mathrm{Ru}_{0.3} \mathrm{~Pb}_{(0.7-x)} \mathrm{Ti}_{x} \mathrm{O}_{2}$ electrodes prepared by thermal decomposition of ruthenium, titanium and lead inorganic salts dissolved in isopropanol. ${ }^{46}$

In addition, the response of the $\mathrm{RuO}_{2} / \mathrm{BDD}$ electrode is also somewhat better than that of the BDD sample while the $\mathrm{PbO}_{2} / \mathrm{BDD}$ electrode is extremely inactive for the OER. In fact, $\mathrm{PbO}_{2}$ electrodes have been largely used as anodes under extreme conditions due to its extended anodic window in aqueous media ${ }^{47,48}$ while $\mathrm{RuO}_{2}$ anodes are commonly reported as appropriate materials to promote the OER reaction..$^{26,49}$ For comparison, it is important to mention that under similar conditions a $\mathrm{PtO}_{\mathrm{x}} / \mathrm{BDD}$ electrode shows the

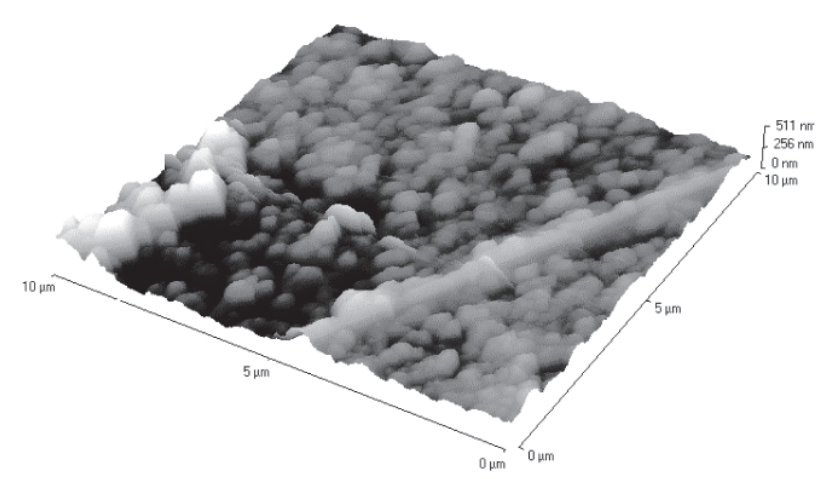

Figure 4. Topological studies carried out by the AFM technique ( $10 \times 10$ $\mu \mathrm{m})$ for BDD electrode modified with Platinum by the Sol-Gel technique. 
onset of the oxidation current for the OER at $\sim 1.6 \mathrm{~V} v s$. HESS as it was previously reported by our group. ${ }^{22}$

Studies of the ethanol oxidation reaction in acid medium were initially carried out using a $\mathrm{PtO}_{\mathrm{x}}$-modified BDD electrode prepared by the Sol-Gel technique with a greater loading than in previous studies. ${ }^{22}$ Figure 4 shows the AFM image $(10 \times 10 \mu \mathrm{m})$ of that surface where it can be observed the presence of Pt oxide "islands" with micrometric size and a rather irregular distribution. This fact indicates that the agglomeration of the Pt metal clusters (having small amounts of $\mathrm{PtO}_{\mathrm{x}}$, as revealed by EDX measurements) on preferential sites of the surface renders a non-homogeneous coating.

To increase the stability of Pt oxide "islands" on de BDD surface, $40 \mu \mathrm{L}$ of a $0.5 \%$ Nafion $^{\circledR}$ solution were evaporated on the electrode surface using a hot air stream thus forming a Nafion ${ }^{\circledR}$ film on the electrode surface. The almost negligible loss of Pt oxide particles after one-thousand voltammetric cycles between the water decomposition reactions for this kind of electrode has been already shown. ${ }^{22}$ In the present case, the modified surface was tested with the ethanol oxidation reaction and the results are presented in Figure 5. These studies were carried out in a $0.5 \mathrm{~mol} \mathrm{~L}^{-1} \mathrm{CH}_{3} \mathrm{CH}_{3} \mathrm{OH}$ $+0.5 \mathrm{~mol} \mathrm{~L}^{-1} \mathrm{H}_{2} \mathrm{SO}_{4}$ solution and show the $1^{\text {st }}$ cycle (solidline), the response after 4 hours of continuous electrolysis at $650 \mathrm{mV} v s$. HESS (dashed-line) and, finally, the further effect of 1000 cycles at $500 \mathrm{mV} \mathrm{s}^{-1}$ (dotted-line) on a $\mathrm{PtO} / \mathrm{BDD}$ electrode. A comparison of the oxidation current densities at $920 \mathrm{mV}$ vs. HESS reveals a very small decrease (6\%) after the electrolysis and a practically insignificant variation after the additional one-thousand voltammetric cycles in

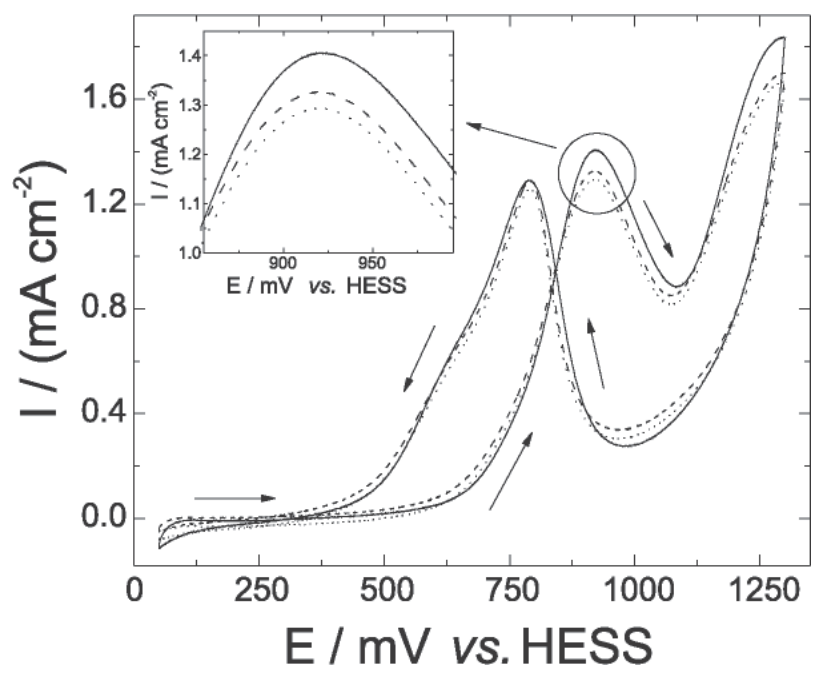

Figure 5. Cyclic voltammograms for ethanol oxidation on a $\mathrm{PtO}_{\mathrm{x}} / \mathrm{BDD}$ electrode in $0.5 \mathrm{~mol} \mathrm{~L}^{-1} \mathrm{CH}_{3} \mathrm{CH}_{2} \mathrm{OH}+0.5 \mathrm{~mol} \mathrm{~L}^{-1} \mathrm{H}_{2} \mathrm{SO}_{4}$ corresponding to: $1^{\text {st }}$ cycle (full line), after 4 hours of continuous electrolysis at $650 \mathrm{mV}$ vs. HESS (dashed line) and after additional 1000 cycles at $500 \mathrm{mV} \mathrm{s}^{-1}$ (dotted line). The insert shows an enlargement of the $1^{\text {st }}$ peak region. $v=$ $20 \mathrm{mV} \mathrm{s}^{-1}$. the same solution. This confirms that the stability of the $\mathrm{PtO}_{\mathrm{x}}-\mathrm{Nafion}{ }^{\circledR}$ coating on BDD is extensive to other electrode reactions. Thus, the stability of this deposit was somewhat higher than that observed on an amperometric biosensor sensitive to ethanol built on a carbon paste electrode modified with alcohol dehydrogenase $(\mathrm{ADH})$, nicotinamide adenine dinucleotide $\left(\mathrm{NAD}^{+}\right)$cofactor and Meldola's blue (MB) adsorbed on silica gel coated with niobium oxide. ${ }^{50}$ Using this biosensor $95 \%$ of the activity was maintained after 300 determinations. Meanwhile, the stability of the Nafion $^{\circledR}$ coated $\mathrm{PtO}_{\mathrm{x}} / \mathrm{BDD}$ was much higher than that observed on a ethanol biosensor based on the enzymatic activity of immobilized (on a nylon mesh) alcohol dehydrogenase, coupled with the electrocatalytic oxidation of NADH. ${ }^{51}$

It is important to point out that the responses for the ethanol oxidation reaction observed in Figure 5 present a similar shape and a reaction onset potential $(\sim 600 \mathrm{mV} v s$. HESS) than those previously reported for polycrystalline platinum electrodes (between 550 and $600 \mathrm{mV} v s$. RHE $)^{52-54}$ and for Pt particles dispersed on carbon $(\sim 600$ $\mathrm{mV} v$ s. HESS $),{ }^{55}$ demonstrating that these responses are only due to the Pt catalyst activity on the BDD surfaces as well as the high purity of deposits. On the other hand, the ethanol oxidation reaction in acid media has a onset potential higher than $1000 \mathrm{mV}$ vs. HESS on the $\mathrm{IrO}_{2} / \mathrm{BDD}, \mathrm{RuO}_{2} / \mathrm{BDD}$ and $\mathrm{PbO}_{2} / \mathrm{BDD}$ electrodes (not shown) in a clear indication of their low electrocatalytic activity for such reaction.

To complete the investigation on the properties of the metal-oxide coatings deposited onto the diamond surface, a Pt oxide deposit was incorporated to one of the previously developed coating. The results are shown in Figure 6 were it can be observed that the incorporation of

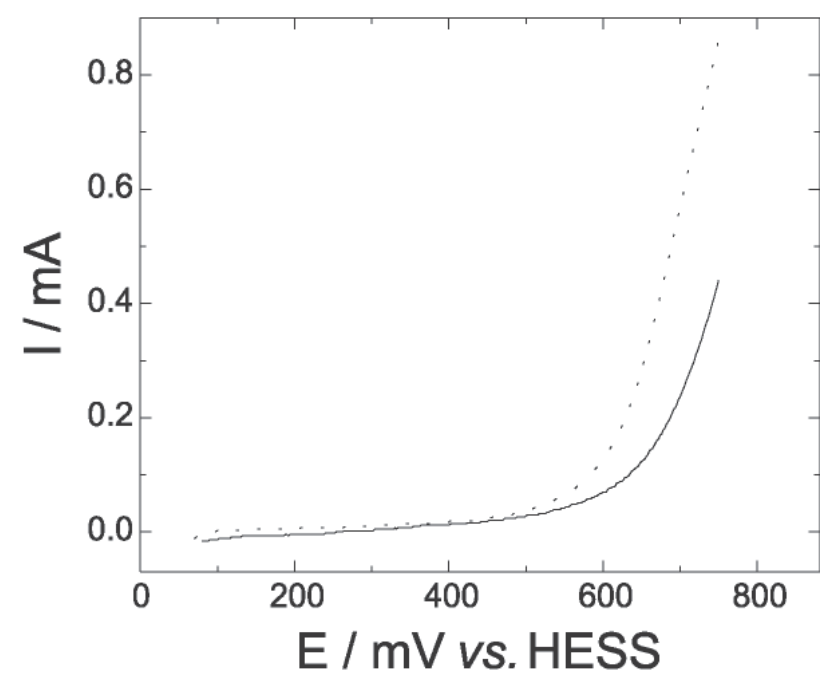

Figure 6. Linear-sweep voltammograms to ethanol oxidation on the $\mathrm{PtO}_{\mathrm{x}} /$ $\mathrm{BDD}$ (full line) and $\mathrm{PtO}_{\mathrm{x}}-\mathrm{RuO}_{2} / \mathrm{BDD}$ (dotted line) electrodes carried out in a $0.5 \mathrm{~mol} \mathrm{~L}^{-1} \mathrm{CH}_{3} \mathrm{CH}_{2} \mathrm{OH}+0.5 \mathrm{~mol} \mathrm{~L}^{-1} \mathrm{H}_{2} \mathrm{SO}_{4}$ solution. $v=20 \mathrm{mV} \mathrm{s}^{-1}$. 
$\mathrm{PtO}_{\mathrm{x}}$ to a $\mathrm{RuO}_{2} / \mathrm{BDD}$ deposit greatly increases the current density and shifts the onset potential by $\sim 100 \mathrm{mV}$ with respect to the pure $\mathrm{PtO}_{\mathrm{x}} / \mathrm{BDD}$ electrode for ethanol oxidation in acid media. This earlier onset potential is probably due to the fact that the ruthenium atoms activate water molecules and provides preferential sites for $\mathrm{OH}_{\text {ads }}$ adsorption at lower potentials than Pt. Abundant $-\mathrm{OH}_{\text {ads }}$ species are necessary to completely oxidize the poisoning intermediates to $\mathrm{CO}_{2} \cdot{ }^{56}$ The good performance of the $\mathrm{PtO}_{\mathrm{x}}$ $\mathrm{RuO}_{2} / \mathrm{BDD}$ electrode and the increased stability of the deposits when using a Nafion ${ }^{\circledR}$ film, suggests the continuation of these studies.

\section{Conclusions}

The results of this investigation clearly show that the Sol-Gel method can be successfully employed to modify the BDD surface and that it constitutes a feasible and simple methodology for the preparation of electrocatalysts for the OER and the ethanol oxidation reactions in acid media.

Although the AFM images indicate that the modified electrode surfaces present sites of heterogeneous deposition, the electrocatalytic activity appears in all cases and the active surface areas increase considerably after application of the metal oxides.

As expected, the $\mathrm{RuO}_{2} / \mathrm{BDD}$ and $\mathrm{IrO}_{2} / \mathrm{BDD}$ electrodes show good electrocatalytic activity for the oxygen evolution reaction (OER) if compared with diamond and/ or $\mathrm{PbO}_{2} / \mathrm{BDD}$ electrodes.

In addition, the use of a Nafion ${ }^{\circledR}$ film greatly improves the stability of the deposits on the BDD surfaces and this property can make possible the use of these systems in practical applications, such as sensors manufacturing or electrochemical combustion of unwanted organic residues. Moreover, the combination of $\mathrm{PtO}_{\mathrm{x}}$ with other metal oxides deposited on a BDD surface could lead to the development of anodes tailored for ethanol oxidation or other important electrochemical reactions

\section{Acknowledgments}

The authors wish to thank the Brazilian Institutions FAPESP (Proc. 01/14320-0), CNPq and CAPES for the scholarships and financial support to this work.

\section{References}

1. Manivannan, A.; Seehra, M.S.; Fujishima, A.; Fuel Process. Technol. 2004, 85, 513.

2. Codognoto, L.; Machado, S.A.S.; Avaca, L.A.; Diam. Relat. Mat. 2002, 11, 1670.
3. Muna, G.W.; Tasheva, N.; Swain, G.; Environ. Sci. Technol. 2004, 38, 3674.

4. Banks, C.E.; Hyde, M.E.; Tomcik, P.; Jacobs, R.; Comptom, R.G.; Talanta 2004, 62, 279.

5. Pedrosa, V.A.; Codognoto, L.; Avaca, L.A.; J. Braz. Chem. Soc. 2003, 14, 530.

6. Pedrosa, V.A.; Codognoto, L.; Machado, S.A.S.; Avaca, L.A.; J. Electroanal. Chem. 2004, 573, 11.

7. Pedrosa, V.A.; Suffredini, H.B.; Codognoto, L.; Tanimoto, S.T.; Machado, S.A.S.; Avaca, L.A.; Anal. Lett. 2005, 38, 1115.

8. Suffredini, H.B.; Pedrosa, V.; Codognoto, L.; Machado, S.A.S.; Rocha-Filho, R.C.; Avaca, L.A.; Electrochim. Acta 2004, 49, 4021.

9. Salazar-Banda, G.R.; Andrade, L.S.; Nascente, P.A.P.; Pizanni, P.S.; Rocha-Filho, R.C.; Avaca, L.A.; Electrochim. Acta, submitted.

10. Bellagamba, R.; Michaud, P.A.; Comninellis, C.; Vatistas, N.; Electrochem. Comm. 2002, 4, 171.

11 Codognoto, L.; Machado, S.A.S.; Avaca, L.A.; J. Appl. Electrochem. 2003, 33, 951.

12. Zhi, J.F.; Wang, H.B.; Nakashima, T.; Rao, T.N.; Fujishima, A.; J. Phys. Chem. B 2004, 107, 13389.

13. Brillas, E.; Boye, B.; Sires, I.; Garrido, J.A.; Rodriguez, R.M.; Arias, C.; Cabot, P.L.; Comninellis, C.; Electrochim. Acta 2004, 49, 4487.

14. Duo, I.; Michaud, P.A.; Haenni, W.; Perret, A.; Comninellis, C.; Electrochem. Solid-State Lett. 2000, 3, 325.

15. De Battisti, A., Ferro, S.; Dal Colle, M.; J. Phys. Chem. B 2001, 105, 1679.

16. Terashima, C.; Rao, T.N.; Sarada, B.V.; Spataru, N.; Fujishima A.; J. Electroanal. Chem. 2003, 544, 65.

17. Salimi, A.; Hyde, M.E.; Banks, C.E.; Compton, R.G.; Analyst 2004, 129, 9 .

18. Tsubota, T.; Tanii, S.; Ida, S.; Nagata, M.; Matsumoto, Y.; Phys. Chem. Chem. Phys. 2003, 5, 474.

19. Kruusma, J.; Banks, C.E.; Compton, R.G.; Anal. Bioanal. Chem. 2004, 379, 700.

20. Ivandini, T.A.; Sato, R.; Makide, Y.; Fujishima, A.; Einaga, Y.; Diamond Relat. Mater. 2004, 13, 2003.

21. Montilla, F.; Morallon, E.; Duo, I.; Comninellis, C.; Vazquez, J.L.; Electrochim. Acta 2003, 48, 3891.

22. Salazar-Banda, G.R.; Suffredini, H.B.; Avaca, L.A.; J. Braz, Chem. Soc. 2005, 16, 903.

23. Honda, K.; Yoshimura, M.; Rao, T.N.; Tryk, D.A.; Fujishima, A.; Yasui, K.; Sakamoto, Y.; Nishio, K.; Masuda, H.; J. Electroanal. Chem. 2001, 514, 35.

24. Yoshimura, M.; Honda, K.; Uchikado, R.; Kondo, T.; Rao, T. N.; Tryk, D. A.; Fujishima, A.; Sakamoto, Y., Yasui, K.; Masuda, H.; Diamond Relat. Mater. 2001, 10, 620.

25. Gao, J.S.; Arunagiri, T.; Chen, J. J.; Goodwill, P.; Chyan, O.; Perez, J.; Golden, D.; Chem. Mater. 2000, 12, 3495. 
26. Mattos-Costa, F.I.; de Lima-Neto, P.; Machado, S.A.S.; Avaca, L.A.; Electrochim. Acta 1998, 44, 1515.

27. Suffredini, H.B.; Cerne, J.L.; Crnkovic, F.C.; Machado, S.A.S.; Avaca, L.A.; Int. J. Hydrogen Energ. 2000, 25, 415.

28. Trinchi, A.; Li, Y.X.; Wlodarski, W.; Kaciulis, S.; Pandolfi, L.; Russo, S.P.; Duplessis, J.; Viticoli, S.; Sensors Acts. A: Phys. 2003, 108, 263.

29. McDonagh, C.; Bowe, P.; Mongey, K.; MacCraith, B.D.; J. NonCryst. Solids 2002, 306, 138.

30. Suffredini, H.B.; Tricoli, V.; Avaca, L.A.; Vatistas, N.; Electrochem. Comm. 2004, 6, 1025.

31. Ferreira, N.G.; Silva, L.L.G.; Corat, E.J.; Trava-Airoldi, V.J.; Diamond Relat. Mater. 2002, 11, 1523.

32. Goeting, C.H.; Jones, F.; Foord, J.S.; Eklund, J.C.; Marken, F.; Compton, R.G.; Chalker, P.R.; Johnston, C.; J. Electroanal. Chem. 1998, 442, 207.

33. Breiter, M.W.; Kammermaier, H.; Knorr, C.A.; Z. Elektrochem. 1956, 60, 37.

34. Gilman, S. In Electroanalytical Chemistry; Bard, A.J., ed., Marcel Dekker: New York, 1967, vol. 2.

35. Woods, R. In Electroanalytical Chemistry; Bard, A.J., ed., Marcel Dekker: New York, 1976, vol. 9.

36. Aschauer, E.; Fasching, R.; Varahram, M.; Jobst, G.; Urban, G.; Nicolussi, G.; Husinsky, W.; Friedbacher, G.; Grasserbrauer, G.; J. Electroanal. Chem. 1997, 426, 157.

37. Brummer, S.B.; J. Phys. Chem. 1965, 69, 562.

38. Biegler, T.; Rand, D.A.J.; Woods, R.; J. Electroanal. Chem. 1971, 29, 269.

39. Gottesfeld, S.; J. Electrochem. Soc. 1980, 127, 1922.

40. Wilson, M.S.; Rauh, R.D.; Biosens. Bioelectron. 2004, $20,276$.

41. Suffredini, H.B.; Machado, S.A.S.; Avaca, L.A.; J. Braz. Chem. Soc. 2004, 15, 16.
42. Swain, G.M.; Anderson, A.B.; Angust, J.C.; MRS Bulletin 1998, $23,56$.

43. Yagi, M.; Tomita, E.; Kuwabara, T.; J. Electroanal. Chem. 2005, 579, 83.

44. Rasten, E.; Hagen, G.; Tunold, R.; Electrochim. Acta 2003, 48, 3945.

45. Terezo, A.J.; Pereira, E.C.; Electrochim. Acta 1999, 44, 4507.

46. Cestarolli, D.T.; De Andrade A.R.; Electrochim. Acta 2003, 48,4137

47. Ho, J.C.K; Tremiliosi-Filho, G.; Simpraga, R.; Conway, B.E.; J. Electroanal. Chem. 1994, 366, 147.

48. Zhang, M; Wilde, C.P.; J. Electroanal. Chem. 1995, 390, 59.

49. Terezo, A.J.; Pereira, E.C.; Mater. Lett. 2002, 53, 339.

50. Santos, A.S.; Freire, R.S.; Kubota, L.T.; J. Electroanal. Chem. 2003, 547, 135.

51. Wu, Q.; Maskus, M.; Pariente, F.; Tobalina, F.; Fernández, V.M.; Lorenzo, E.; Abruña, H.D.; Anal. Chem. 1996, 68, 3688.

52. Li, N.H.; Sun, S.G.; Chen, S.P.; J. Electroanal. Chem. 1997, 430, 57.

53. Chen, S.; Schell, M.; J. Electroanal. Chem. 1999, 478, 108.

54. Camara, G.A.; Iwasita, T.; J. Electroanal. Chem. 2005, 578, 315.

55. Calegaro, M.L.; Suffredini, H.B.; Machado, S.A.S.; Avaca, L.A.; J. Power Sources 2005, in press.

56. Gurau, B.R.; Viswanathan, R.; Liu, R.X.; Lafrenz, T.J.; Ley, K.L.; Smotkin, E.S.; Reddington, E.; Sapienza, A.; Chan, B.C.; Mallouk, T.E.; Sarangapani, S.; J. Phys. Chem. B 1998, 102, 9997.

Received: September 8, 2005

Published on the web: February 6, 2006

FAPESP helped in meeting the publication costs of this article. 